\title{
An Empirical Analysis of the Sustainability of Public Debt in Ghana
}

\author{
Gideon Amankwah'1, Grace Ofori-Abebrese², Kofi Kamasa ${ }^{3}$ \\ ${ }^{1}$ Training and Research, Greenfield Education Group, Accra, Ghana \\ ${ }^{2}$ Department of Economics, Kwame Nkrumah University of Science and Technology, Kumasi, Ghana \\ ${ }^{3}$ Department of Management Studies, University of Mines and Technology, Tarkwa, Ghana \\ Email: amankwahgideon83@gmail.com,ofori35@yahoo.com, kofikamasa@hotmail.co.uk
}

How to cite this paper: Amankwah, G., Ofori-Abebrese, G. and Kamasa, K. (2018) An Empirical Analysis of the Sustainability of Public Debt in Ghana. Theoretical Economics Letters, 8, 2038-2054. https://doi.org/10.4236/tel.2018.811133

Received: April 5, 2018

Accepted: July 29, 2018

Published: August 2, 2018

Copyright (c) 2018 by authors and Scientific Research Publishing Inc. This work is licensed under the Creative Commons Attribution International License (CC BY 4.0).

http://creativecommons.org/licenses/by/4.0/

\section{cc) (i) Open Access}

\begin{abstract}
Governments have the zeal to meet the developmental needs of their countries but due to their inability to raise the necessary revenue to commensurate their expenditure, the fiscal balance of their countries has deteriorated. The surge in the public debt of Ghana has caused much anxiety on the sustainability of such fiscal measures. The study is set out to investigate if Ghana's debt is sustainable in the long-run and also ascertain if the solvency condition holds for the country. Secondary data spanning from 1990 to 2016 was used. The Autoregressive Distributed Lag (ARDL) method was adopted to estimate the relationship between the variables. The study found that fiscal policy makers react to rising debt levels by adjusting primary balance by $0.087 \%$ when debt rises by $1 \%$. Since this satisfies the intertemporal government budget constraint (IGBC) condition it was then concluded that the debt level of Ghana is sustainable. Government expenditure and its revenue cointegrate at 5\% significance level and a unit increase in government revenue pushes government expenditure by $0.73 \%$. Also the expenditures reaction to increase in revenues satisfies the Wald test restriction $\alpha_{1}=1$, implying that the solvency condition holds for Ghana. It is recommended to fiscal authorities to check primary fiscal balance through the business cycle in order to foster stable and higher economic growth while ensuring debt is also sustainable.
\end{abstract}

\section{Keywords}

Sustainability, Output Gap, Expenditure Gap, Public Debt, Primary Fiscal Balance, Autoregressive Distributed Lag (ARDL)

\section{Introduction}

The central government's inability to finance its projects and policies through 
tax revenue has been a challenge since independence. The deficit created as a result is often financed through borrowing from domestic sources, external sources or the central bank. This incessant dependence on loans to finance Ghana's fiscal deficit has seen the debts rise over the years. Despite the gains in GDP growth, the rise in public debt has caused many to worry about the sustainability of public debt in Ghana. From Figure 1 it is observed that, from 1990 to 1993 the public-debt-to-GDP ratio was on an increasing path, while GDP growth was oscillating. The public-debt-to-GDP ratio moved from 28 percent to 51 percent between 1990 and 1993 respectively, while GDP growth also increased from about 3.3 percent to 4.85 around the same period. The debt burden surged to 76 percent in 1994 and sharply declined to 57 percent in 1998. However, this could not be sustained as the public-debt-to-GDP ratio increased to 78 percent in 1999. Within these periods GDP growth averaged around 4.21 percent between 1994 and 1999. Domestic debt trend can lead to an increasing debt burden which can impact negatively on the economy [1]. This trend was seen in the years discussed above. By entering the millennium, the debt ballooned to 112 percent of the GDP. This abnormal surged, raised more anxiety on the sustainability of the debt burden. Afterwards the country recorded marginal decreases of the public-debt-to-GDP ratio from the 112 percent in 2000 to 87 percent, 82 percent and 74 percent from 2001, 2002 and 2003 respectively.

Although the debt burden saw a decline, this was above the sustainability threshold of 70 percent among the ECOWAS economic zone. The decline in the public debt figures within that period is attributed to the government decision to join the highly indebted poor countries (HIPC) in 2001. The HIPC benefits brought the level of external debt down. The initiative was to put the external debt to sustainable levels as most of the debts were forgiven. By 2004 the country

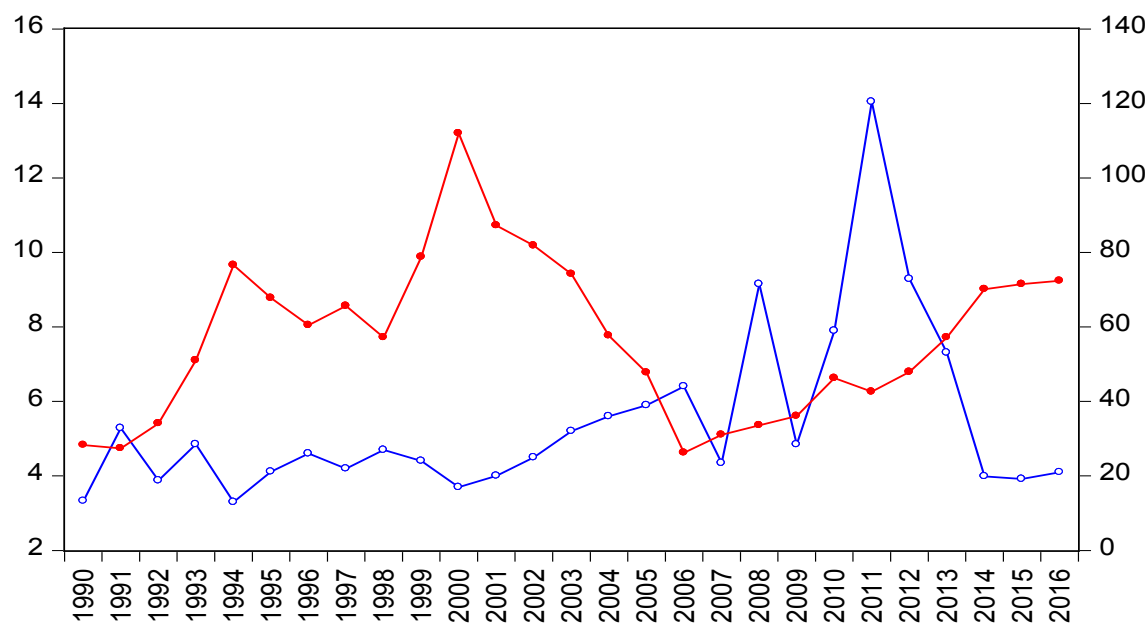

$\multimap$ GDPgr — pdgdp

Figure 1. Relationship between GDP growth and public debt to GDP ratio. Source: The World Bank, and the Ministry of Finance Ghana. Figure generated from Eviews 9 econometric package. 
had completed the programme having achieved most of the conditions set in the agreement i.e. public-debt-to-GDP ratio was at 58 percent which was very remarkable. GDP growth also recorded marginal increases. From 4 percent, it increased to 4.5, 5.2 and 5.6 percent in 2001, 2002, 2003 and 2004 respectively. As at the end of 2006, the public-debt-to-GDP ratio and GDP growth stood at 26 percent and 6.4 percent respectively. Having achieved this remarkable feat, there was an increase in the public debt figures. Correspondingly, the debt burden increased 31 percent and 34 percent in 2007 and 2008. While growth in GDP also increased from 4.4 percent to 9.2 percent between 2007 and 2008 .

Soon after bringing the public debt to sustainable, the country's debt began to escalate as can be seen from Figure 1. The public-debt-to-GDP figure increased to 46 percent by 2010, while GDP growth also declined to 7.9 percent. However, the public debt declined to about 43 percent of GDP in 2011, the lowest to be recorded after 2006. The steep decline is accounted for by, the increase in GDP figure to about 14 percent as a result of the production of crude oil in commercial quantities. This could not be sustained. By 2012, the public debt had increased to 48 percent of GDP. Then it further increased to 57, 70, 71 percent respectively. As at December 2016, the public-debt-to-GDP had increased to 72.4 percent, the highest to be ever recorded after the Ghana joined the HIPC initiative. On the other hand, GDP continually declined from 9.3 percent in 2012 to 3.9 percent in 2015. In 2016 GDP growth gained marginally to 4.1 percent.

According to [2] large external debt accumulated by several developing countries hampers their economic growth and are a constraint to poverty alleviation. While [3] argue that public debt acts as a national asset which is necessary for the country's economic prosperity. With these diverse opinions expressed, it is inconclusive to suggest that Ghana's public debt is either on a sustainable path or an unsustainable path especially when public-debt-to-gdp figures have been fluctuating over the years. This calls for thorough empirical analysis to be done to ascertain the sustainability of public debt in Ghana.

Ghana is faced with high risk of debt sustainability as there has been an increase in the overall debt stocks which is largely driven by loose fiscal policy, weak financing terms and external pressures due to high interest payments on external debt [4]. The study further opines that as a result of high exchange rate, future financing conditions turns to be costly which is likely to affect the debt sustainability of the country. Similarly, [5] asserts that the public debt of Ghana has deteriorated in recent years with a high risk of debt distress and vulnerability. According to the findings in [5], the ratio of debt service to revenue is on an increasing path which is beyond the long term threshold. With the growing concern about the sustainability of the country's debt, Ghana requested for a three year Extended Credit Facility (ECF) agreement with the International Monetary Fund (IMF), which was anchored on the second Ghana Shared Growth and Development Agenda (GSGDA II). It aimed at a sizeable and front loaded fiscal adjustment to restore debt sustainability, rebuild external buffers 
while safeguarding financial sector stability [6]. Also the Medium Term Debt Management Strategy (MTDS) was developed for 2016-2018 to guide annual borrowing to incorporate the risk elements that has been identified in the debt portfolio. The exposure to overall debt vulnerability influenced [4] and [5] to describe the Ghanaian economy as being debt distressed. Similarly, [7] acknowledges that as at 2016, the debt stock has reached beyond the sustainability thresholds of 70 percent. However, none of them point to whether considering the scale of economic growth and the measures such as the public financial management framework to control overall government spending in both the short and medium term can impact on the sustainability of public debt in Ghana.

This poses a great need for a thorough study to be done to investigate if public debt is sustainable. The study empirically assesses if the fiscal solvency condition holds for Ghana and also the relationship between government expenditure and its revenue in the long run. In this regard, the paper employed the autoregressive distributed lag technique to empirically ascertain if the fiscal solvency condition hold for Ghana and also find out how dependent variables such as real government expenditure and revenue, output and expenditure gaps contribute to debt sustainability in Ghana.

The rest of the paper is organized as follows; Section 2 reviews the relevant literature, Section 3 presents the data source and research methodology while Section 4 analyzes the estimated models on public debt sustainability. Section 5 concludes the study.

\section{Literature Review}

The dynamics of public debt are in two folds; gross debt and net debt. One ought to differentiate gross debt from net debt [8]. Gross debt refers to the total financial liabilities less the financial assets of government and net debt reflects essentially, how much debt is left on the balance sheet assuming the government pays all its debt obligations with the available revenue [8]. On the other hand, public debt is the net stock of outstanding government debt [9].

Public debt in many instances acts like the double edged sword. It can improve the wellbeing of the citizens when prudently used while when it is in excess or imprudently managed can lead to the collapse of the economy. Public debt as a national asset other than liability which is necessary for the country's economic prosperity [3]. Contrary, uncontrolled levels of public debt beyond certain ratios subject the economy to more and severe financial crises [2]. It is worth noting that the ability of government to sustain the debt level depends largely on its ability to raise revenue or increase its fiscal capacity.

Debt burden as explained to mean the total amount of private consumption goods that is sacrificed by households at the time the amount borrowed are spent, consequently, the generation at the time of the borrowing must bear the cost of the public project [10]. They argued further that if bonds are purchased 
out of the consumption of current generation then the burden will eventually be shifted to the future. This is in sharp contrast to the view of [11] who maintained that there is no burden on future generations if the project is financed out of the consumption of the current generation. They however failed to assess whether the projects are productive or unproductive. Ricardo analyzed the effect of public debt in the context of budget deficit and concluded that public deficit has no macroeconomic (public investment and external account) impact in the long run [12]. Opposing to this view, the traditionalist reported that at a given savings rate, an increase in government budget deficit leads to a drop in private investment and external current account.

Debt is inevitable for without it economies would be slow and macroeconomic volatility would be higher than expected [13]. In accordance, [14] highlighted that government debt performs three functions 1) a stabilizing function, 2) a bridging function and 3) a burden-shifting function. Basing their empirical analysis on the German economy, they concluded that, for government to stabilize the macro economy, they should pay the debt they owe when the economy is showing signs of overheating and should be willing to run up more debt in the periods of recession.

The volatility of business cycle has a potential effect on the fiscal position of a country [15]. The Stability of fiscal policy depends on the primary balance which needs to react positively to rising output level and negatively to a decreasing output level [15]. For he reasoned that reduction in budget deficit results in a positive fiscal impact to aggregate demand. In accord with [15] [16] and [17] reported that the impact of primary fiscal balance on changes in the business cycle can be used to determine fiscal stability. It has been revealed that volatility also have a long term effect on growth especially for countries with underdeveloped financial system because lower uncertainties in the macro economy can boost investment and enhance social capital [18].

The argument of debt sustainability has been explained to mean the ability to sustain a constant debt-GDP ratio over a period of time. Public debt is unsustainable when debt to GDP ratio reaches an excessive threshold. Sustainable fiscal policy as the one that permits debt-GDP ratio in the short term to return to its original level after some excessive deviation [19]. The traditional approach to measuring debt sustainability is the use of Domar's equation which states that unsustainable public debt is when the rate of growth in income is higher than interest rate i.e. the cost of public borrowing.

Studies such as [20] [21] and [22] on debt sustainability have all been concerned with sustainability and international debt, sustainability of African debt and what is sustainable public debt respectively. In their approach they consider the nation to be fiscally solvent when the burden of external debt servicing and ratio of debt service to export and import are analyzed. Since foreign debt can be serviced only through exports, the external public debt to exports ratio is used as an indicator of the external foreign debt level sustainability. 
"National Solvency" is where growth of external debt servicing burden and debt servicing export-import ratios are analyzed. For public debt to be sustainable the following conditions must hold; 1) Equilibrium in balance of payment have to be achieved without resorting to the use of reserve assets, loans and credit from the IMF etc. to deal with payments imbalance. 2) The level of indebtedness must be low to prevent the problem of future debt servicing. To deal with this one, indebtedness indicators such as debt to GDP ratio and debt to export ratio must be computed.

In the OECD, using the gap between sustainable tax rate over a period, the tax rate that leaves debt to GNI ratio unchanged and current tax rate as indicators for short, medium and long run respectively, [23] found that, the short and medium term were positive and large among the countries. In the long run, aging population was found to be a great threat to fiscal sustainability. The study also suggests that many countries were faced with high prospects of debt to GNI ratios. Studying on external debt and growth in 93 developing countries over 1969 to 1998 and using panel dataset, [24] concluded that when external debt level is beyond 35 - 40 percent of GDP it has a negative effect on GDP per capita for the NPV. Also high debt reduces growth by largely lowering the efficiency of investment. Assessing the structure of government budget and the public debt dynamics in 15 European Union countries, Norway and US between 1960 and 2002, [25] found that, reducing government expenditure are more crucial for reducing debt than increasing in revenue. They obtained persistent debtaugmenting effects of tax reductions. By conducting a cross-country empirical analysis of fiscal solvency based on the DSGE conditions, [26] found that a positive and statistically significant change in primary fiscal balance when public debt changes is enough for fiscal solvency condition to hold. Emerging economies react swiftly and hence converges to lower mean debt to GDP ratio. In the Euro Area [27] investigated the impact of high and growing government debt on economic growth. The study covering a 40 year period from 1970 suggest the impact of public debt on GDP growth as non-linear. However, debt beyond 70 percent to 80 percent of GDP begins to have adverse impact on growth. If the debt is unchecked and goes beyond 90 percent to 100 percent of GDP this will negatively impair growth in the long run. Further, [27] found that annual change in debt to budget deficit ratio are negatively and linearly inclined to GDP per capita. Explaining the interest-rate growth differential underlying government debt dynamics among 23 OECD countries, [28] used panel estimation and found out that the difference between the interest rate paid on government debt and growth rate are key to assessing the sustainability of fiscal policy.

Researching on fiscal consolidation, public debt and output dynamics in the Euro area and using time varying fiscal multipliers model, [29] suggested that not all European Monetary Union countries would likely reach debt to GDP ratio of 60 percent and above by 2032. Because output gap was nearly closed in Germany and therefore it would not be prudent for them to implement expansionary fiscal policy as this will lead to a low spillover effects which will not be 
significant. The study proposed an alternate for the countries that will not be able to reach 60 percent of debt to GDP ratio by 2032 to spread their austerity measure and link it to periods where fiscal multiplier will be weaker. Using Bohn's fiscal reaction function, [22] investigated what makes public debt sustainable in United States and Europe. The structural approach based calibrated DSGE with fully specified fiscal sector and the third approach assumes government cannot commit to repay its domestic debt. Their findings raised serious issues on the sustainability of fiscal adjustment in advanced countries.

By examining the sustainability of fiscal policy in Ghana through the fiscal reaction function, using ARDL [30] concluded that government's fiscal behavior is consistent with IGBC but there was the presence of fiscal pressures which were largely as a result of fiscal excesses during election cycles. On managing domestic debts in Ghana, [1] emphasized on the growing trend of domestic debt resulting in a vicious cycle of increasing debt burden with dire consequences on the economy. He proposed diversification of some unproductive national assets and the proceeds used to finance the debt. Studying the impact of external debt on economic growth in Ghana to determine the presence of crowding out effect from related debt for the period 1970-1999, [31] used the short run Vector error-correction model which led to the conclusion that the existence of a debt overhang effect is as a result of high debt accumulation which significantly negates economic growth and also established that while GDP growth increases with external debt inflows. Eventually economic growth decreases with debt servicing resulting in a crowding out effect. Emphasizing on public debt and economic growth in Ghana [32] revealed that there is a positive and significant long-run relationship between public debt and economic growth and further recommended the use of public debt to finance very high priority projects to realize the full benefits of public debts in Ghana.

\section{Data and Methodology}

\subsection{Data Source and Description}

The study adopted the Model Based Sustainability Framework by ([33] [34]) and the Present Value Budget Constraint (PVBC) by [35] in specifying the deficit of Ghana's budget. Annual time series data span from 1990 to 2016 was used for the study. Data for primary fiscal balance (dependent variable), public debt to GDP, real GDP, government revenue, government expenditure were obtained from the World Bank database and the Ministry of Finance, Ghana. Output gap is the difference between the cyclical components of real GDP obtained by filtering it with Hodrick-Prescott filter with a smoothing parameter of 100. Expenditure gap is the percent deviation of government final consumption obtained from the World Bank database detrended with Hodrick-Prescott with a smoothing parameter of 100 .

\subsection{Model Specification}

By using both the reduced form of the budget constraint and the equilibrium 
sset pricing conditions which imposes the No Ponzi game condition yields the IGBC condition specified as

$$
\operatorname{pdgdp}_{t-1}=\operatorname{pbgdp}_{t}+\sum_{j=1}^{\infty} E_{t}\left[\operatorname{MRS}\left(c_{t+j}, c_{t}\right) \operatorname{pbgdp}_{t+j}\right]
$$

where pdgdp is the primary fiscal balance as ratio of GDP, $\operatorname{MRS}\left(c_{t+j}, c_{t}\right)$ is the marginal rate of substitution in consumption between period $t+j$ and period $t$, $\operatorname{pdgdp}_{t-1}$ is the initial public debt. IGBC condition is the identical fiscal solvency condition that underlies the concept of sustainable debt. For pdgdp $t_{t-1}$ to be sustainable, it should match with the expected present discounted value of a given future primary fiscal balance. This paper adopts the convention that $\tau_{t}-g_{t}=\operatorname{pdgdp}_{t}$.

\section{1) Model Based Sustainability Framework (Fiscal Reaction Function)}

The model based approach was first developed by [36] to analyse the debt situation in US by evaluating the mean-reverting properties of the debt variable using unit root test. This was developed further by ([33] [34]).

For MBS test, solvency condition will hold when there is a linear and increasing relationship between primary balance-to-GDP ratio and initial debt-to-GDP ratio, after controlling for other determinants measured as output and expenditure gaps. This shows there is a positive and significant relation when primary fiscal balance is regressed on the lagged level public debt [33]. By implication, increase in public debt should be consistent with increase in primary fiscal balance to prevent public debt from exploding. However this study include other variables to augment the model since other variables such as economic, political and institutional factors can affect primary balance in fiscal policies. The study used two alternative approaches of temporary fluctuations in government outlays and GDP. The first set that uses the cyclical components of those detrended by the HP filter.

The reduced-form long run specification of primary fiscal balance is in the form (as model 1):

$$
\operatorname{pbgdp}_{t}=\beta_{0}+\beta_{1} \operatorname{pdgdp}_{t-1}+\beta_{2} \text { outputgap }_{t}+\beta_{3} \operatorname{expendgap~}_{t}+\varepsilon_{t}
$$

where the primary fiscal balance-to-GDP ratio is $\operatorname{pbgdp}_{t}$, the previous public debt-to-GDP ratio is $\operatorname{pdgdp}_{t-1}$, other variables that affects the long run solvency requirement are output gap ( outputgap $_{t}$ ) expenditure gap is expendgap $_{t}$, and the error term with zero mean and constant variance is $\varepsilon_{t} \cdot \beta_{1}, \beta_{2}, \beta_{3}$ are parameters while $\beta_{0}$ is the intercept term. The output gap used in the econometric model captures the influence of business cycle and expenditure gap also captures the temporary increase in government purchases (see [33] and [37]). The proof of Equation (2) requires that both output gap and expenditure gap must be bounded and the GDP's present value must also be finite. The intuition here is that, with primary balance changing by a positive factor $\beta_{1}$ when debt rises, increase in debt in periods $j$ ahead is reduced by $\left(1-\beta_{1}\right)^{j}$. The NPG condition and thus the IGBC hold as

$$
j \rightarrow \infty: \sum_{j=1}^{\infty} E_{t}\left[\operatorname{MRS}\left(c_{t+j}, c_{t}\right) \operatorname{pbgdp}_{t+j}\right] \approx\left(1-\beta_{1}\right)^{j} \operatorname{pbgdp}_{t} \rightarrow 0
$$


By assuming Equation (2) is a valid cointegration equation in the long run, it can be equivalent to the sparing short run error correction model shown as:

$$
\Delta \operatorname{pbgdp}_{t}=\beta_{0}+\beta_{1} \Delta \operatorname{pdgdp}_{t-1}+\beta_{2} \text { outputgap }_{t}+\beta_{3} \operatorname{expendgap~}_{t}+\mu_{t}
$$

where the lagged error term from the co-integrating equation shown in equation 2 with zero mean and constant variance is $\mu_{t}$, the operator of the first difference is $\Delta$. More importantly, $\beta_{1}$ is the basic parameter to test fiscal solvency. A positive $\beta_{1}$ value shows government tries to increase positive primary balance to react to an increase in public debt to satisfy the IGBC condition. According to [38] for fiscal solvency condition to hold the size of the coefficient should be positive and significant.

This framework have been applied by ([22] [23] [28] [34] [39]-[44]) on public debt sustainability to provide empirical test on fiscal solvency.

2) Determining the Sustainability between Government Revenues and

\section{Expenditure}

To establish whether Equation (1) would still hold, the study investigated if there exist cointegration between government expenditures and its revenues which is considered to be consistent with the IGBC. This is due to the restriction imposed by the IGBC condition that revenues and expenditures do not diverge from each other in the long run (see [35] and [45]).

$$
\begin{gathered}
G_{t} \approx \tau_{t} \\
G_{t}=\alpha_{0}+\alpha_{1} \tau_{t}+\varepsilon_{t}
\end{gathered}
$$

where, $G_{t}$ is government expenditure, $\tau_{t}$ is government revenues, $\alpha_{0}$ as the constant term shows the extent of drift in parameters, $\alpha_{1}$ shows how much changes in government revenues affect government expenditure and $\varepsilon_{t}$ is the error term.

By imposing a linear restriction $\alpha_{1}=1$ on Equation (5b) the study test for the significance of the cointegrating vector $\alpha_{1}$. Statistically significant $\alpha_{1}$ value of one implies a strong sustainability of budget deficit in Ghana. On the contrary primary fiscal balance will be weakly sustainable if there is a level of cointegration between government expenditure and its revenue but $0<\alpha_{1}<1$. However, if $\alpha_{1} \leq 0$ then no matter the level of cointegration, primary fiscal balance will be unsustainable (see [46]).

If $G_{t}$ and $\tau_{t}$ are cointegrated, the reduced form of the error correction model can be presented as

$$
\Delta G_{t}=a_{0}+a_{1} \mathrm{ecm}_{t-1}+a_{2} \Delta \tau_{t}+\mu_{t}
$$

where $\Delta$ is the first difference operator, $\mathrm{ecm}_{t-1}$ is the lagged value of the error correctional term. If $G_{t}$ and $\mu_{t}$ are stationary, then it implies the right hand side is also stationary.

Because revenue to GDP ratio is a necessary factor to differentiate between fiscal structures in advanced and developing economies, by lagging revenue-to-GDP ratio the study was able to account for the capacity of fiscal institutions to primary fiscal balance sustainable (see, [30] [37]). 


\section{3) A Priori Assumptions}

Public debt-to-GDP is expected to have a positive relation with primary balance. The intuition here is that, a positive conditional reaction to primary fiscal balance-to-GDP to an increase in debt-to-GDP means, at a particular shock level in an economy, fiscal authorities react positively to changes in public debt by systematically adjusting to primary surplus (see [26] [34] [47]). Consequently the study expects primary balance-to-GDP ratio to be generally positive with the coefficient of public debt (see, [26] [30] [34] [47]) when public debt changes.

The sensitivity of the primary fiscal balance to changes in output gap presumes that growth gyrations reflect a mix of shocks in demand and supply. Output gap is expected to reflect the changes in temporary demand fluctuations. It is expected that output gap will exert a positive effect on primary balance. While the widening of the expenditure gap results in the deterioration of primary balance.

\section{Empirical Results and Discussions}

\subsection{Test for Unit Root and Cointegration}

The study tested for the stationarity of the variables by the use of Augmented Dickey-Fuller (ADF) and the Phillips-Perron (PP) to find out if unit root is present in the times series dataset. Presented in Table 1 below is the results for the stationarity test at the levels and the first order.

The presence of unit root yields spurious results which may be misleading. From Table 1 primary fiscal balance-to-GDP ratio (pbgdp), public debt-to-GDP ratio and log of government revenue as a ratio of GDP (lnrev) were all not stationary at their levels. They all however became stationary at the first difference and they were statistically significant at 1 percent. Since the variables consist of both I (0) and I (1) the study uses the bound test conintegration to test for the existence of long run relationship.

The results from Table 2 indicates that there exist a long-run relationship

Table 1. Stationarity test.

\begin{tabular}{|c|c|c|c|c|}
\hline \multirow[b]{3}{*}{ Variable } & \multicolumn{2}{|c|}{$\mathrm{ADF}$} & \multicolumn{2}{|c|}{ PPerron } \\
\hline & \multicolumn{2}{|c|}{ Test Statistic } & \multicolumn{2}{|c|}{ Test Statistic } \\
\hline & $\mathrm{I}(0)$ & $\mathrm{I}(1)$ & $\mathrm{I}(0)$ & $\mathrm{I}(1)$ \\
\hline Pbgdp & -2.471 & $-5.669^{* * *}$ & -2.468 & $-5.659^{* * *}$ \\
\hline pdgdp & -1.886 & $-4.144^{\star * \star}$ & -2.022 & $-4.126^{* * *}$ \\
\hline Outputgap & $-3.650^{\star *}$ & $-7.734^{\star * *}$ & $-3.684^{\star *}$ & $-7.951^{\star * *}$ \\
\hline Expendgap & $-3.927^{* * *}$ & $-8.266^{\star * *}$ & $-3.844^{* * *}$ & $-8.642^{* * *}$ \\
\hline Lnexp & $-2.682^{\star \star}$ & $-4.898^{\star * *}$ & $-2.769^{* *}$ & $-4.900^{\star * *}$ \\
\hline Lnrev & -1.989 & $-6.129^{* * *}$ & -1.935 & $-6.370^{* * *}$ \\
\hline
\end{tabular}

$* * * \& *$ denotes $1 \%, \& 5 \%$ significance levels. NB. The null hypothesis is that the series is non-stationary or contains a unit root. The simulated critical values of MacKinnon table are compared with the test statistics for both ADF and PP. The PP test bandwidth selection is based on Newey-West. I (0) and I (1) are the levels and first difference operators respectively. Source: Authors' own computation. Data from the World Bank, and the Ministry of Finance Ghana. All results are obtained from Stata 14 econometric package. 
Table 2. ARDL bound test cointegration.

\begin{tabular}{ccccccc}
\hline \multicolumn{7}{c}{ Critical value bounds of F-statistic: Intercept and Trend } \\
\hline \multicolumn{2}{c}{$90 \%$} & \multicolumn{2}{c}{$95 \%$} & \multicolumn{2}{c}{$99 \%$} \\
\hline \multirow{2}{*}{ F-Statistic } & Lower & Upper & Lower & Upper & Lower & Upper \\
& Bound & Bound & Bound & Bound & Bound & Bound \\
$5.636^{* * *}$ & 2.72 & 3.77 & 3.23 & 4.35 & 4.35 & 5.61 \\
\hline
\end{tabular}

Critical Values From [48]. Source: Authors' own computation. Data from the World Bank, and the Ministry of Finance Ghana. All results are obtained from Stata 14 econometric package.

among the variables under estimation since the lower and the upper bound were significant at 1 percent and lower than the critical value of F-statistics.

\subsection{Model Based Sustainability Framework Results}

Considering the unique results of the various set of models, the study then proceeded to estimate the exact nature of the long run relationship between the variables and how significant or insignificant they would exhibit statistically. Test results are presented in Table 3. The ARDL result presented shows there is a positive relation between primary fiscal balance to GDP ratio and public debt to GDP ratio in Ghana. This shows that fiscal authorities react to rising debt by adjusting primary fiscal balance by 0.087 percent when there is 1 percent increase in public debt, this is significant at 10 percent. The study also observed asymmetric relation between the output gap and the primary fiscal balance. An increase in output gap by 1 percent decreases primary fiscal balance-to-GDP by 0.087 percent at a 1 percent significance level. This implies there is the existence of strong procyclical fiscal policy in Ghana.

In addition, an increase in the expenditure gap by 1 percent increases the primary fiscal balance by 0.19 percent although not statistically significant. As a developing Country the results show how fiscal authorities by adjusting to rising debt levels react to changes in fluctuations in output and expenditure (see [26] [49] [50]. These outcomes reveal that solvency condition hold for Ghana and this is confirmed by the studies of [20] and [26].

\section{Short run dynamic results}

The short run error correction model was estimated to identify the short run dynamics of the variables. The results are presented in Table 4. Unlike the long-run results, primary fiscal balance is negatively related to its previous development, this suggests policy makers analyze the development of the previous deficit indicator in Ghana and do not react aggressively to rising debt levels in the short run. Previous primary fiscal balance reduces current fiscal balance by 0.057 percent. Similarly, a percentage increase in the public debt deteriorates primary balance by 0.088 percent and this was significant at 5 percent. This shows fiscal authorities do not pay much attention to rising debt levels in the short run. It can be concluded that, the public debt of Ghana is not sustainable in the short-run as policy makers react negatively to rising debt levels. Unlike the 
Table 3. ARDL Long run relationship in model 1.

\begin{tabular}{cccc}
\hline \multicolumn{2}{c}{ ARDL regression based on AIC } & \multicolumn{2}{c}{ Dependent variable: pbgdp } \\
\hline Regressor & Coefficient & Standard Error & T Statistic \\
\hline Pdgdp & 0.087 & $(0.048)$ & $1.80^{\star}$ \\
Outputgap & -0.087 & $(0.029)$ & $-3.01^{* * *}$ \\
Expendgap & 0.191 & $(0.274)$ & 0.70 \\
Constant & -9.354 & $(2.028)$ & $-4.61^{* * *}$ \\
& \multicolumn{2}{c}{ Model Criteria } \\
Log likelihood & -38.001468 & Adj R-squared & 0.53981514 \\
R-squared & 0.7507332 & Root MSE & 1.5343141 \\
\hline
\end{tabular}

$* * *, * * \& *$ denotes $1 \%, 5 \%$ \& $10 \%$ Significant levels respectively. Source: Authors' own computation. Data from the World Bank, and the Ministry of Finance Ghana. All results are obtained from Stata 14 econometric package.

Table 4. ARDL short run relationship in model 1.

\begin{tabular}{cccc}
\hline \multicolumn{2}{c}{ ARDL regression based on AIC } & \multicolumn{2}{c}{ Dependent variable: pbgdp } \\
\hline Regressor & Coefficient & Standard Error & T Statistic \\
\hline Pbgdp (LD) & -0.0571 & $(0.234)$ & -0.24 \\
pdgdp & -0.088 & $(0.03)$ & $-2.88^{* *}$ \\
Outputgap & 0.048 & $(0.026)$ & $1.88^{*}$ \\
Expendgap & -0.034 & $(0.171)$ & -0.20 \\
ecm & -0.732 & $(0.2472)$ & $-2.96^{* *}$ \\
\multicolumn{1}{c}{ Model Criteria } & \multicolumn{2}{c}{ Model Diagnostic } \\
Log likelihood & -38.001468 & DW d-statistic & 1.744423 \\
R-squared & 0.7507332 & Serial Correlation & 0.4374 \\
Adj R-squared & 0.53981514 & Heteroskedasticity & 0.8011 \\
Root MSE & 1.5343141 & Normality & 0.449 \\
& & Functional form & 0.9672
\end{tabular}

$* * *, * * \&{ }^{*}$ denotes $1 \%, 5 \%$ \& 10\% Significant levels respectively. Source: Authors' own computation. Data from the World Bank, and the Ministry of Finance Ghana. All results are obtained from Stata 14 econometric package.

Table 5. ARDL bound test cointegration.

\begin{tabular}{|c|c|c|c|c|c|c|}
\hline \multicolumn{7}{|c|}{ Critical value bounds of F-statistic: Intercept and Trend } \\
\hline \multirow{3}{*}{ F-Statistic } & \multicolumn{2}{|c|}{$90 \%$} & \multicolumn{2}{|c|}{$95 \%$} & \multicolumn{2}{|c|}{$99 \%$} \\
\hline & Lower & Upper & Lower & Upper & Lower & Upper \\
\hline & Bound & Bound & Bound & Bound & Bound & Bound \\
\hline $6.573^{\star *}$ & 4.04 & 4.78 & 4.94 & 5.73 & 6.84 & 7.84 \\
\hline
\end{tabular}

Critical Values From [48]. Source: Authors' own computation. Data from the World Bank, and the Ministry of Finance Ghana. All results are obtained from Stata 14 econometric package.

long-run results output and expenditure gaps assumes their correct sings. Primary fiscal balance react positively to output gap in the short run. A unit increase in output gap improves the primary balance by 0.048 which was significant at 10 percent. Though cyclical deficits may spur growth, the inevitable increase in debt levels which leads to a rise in debt service make persistence deficits risky to economic growth [51]. While they react negatively to expenditure gaps 
in the short-run.

From Table 4, the short run model exhibited convergence to equilibrium in the long run from a temporal shock. The coefficient of the error correction term was negative and statistically significant at 5 percent. This implies that when primary balance deviates from its trend in the short run, it quickly adjust back to its long run trend. The ECM coefficient of -0.73 implies $73 \%$ of disequilibrium out of the shock in the short run converges back to equilibrium in the long run. This means that any disequilibrium within the short run public debt dynamics in Ghana is quickly adjusted and converged back to equilibrium in the long run.

\subsection{Sustainability between Government Revenues and Expenditure}

From Table 5 it was observed that the government revenue and its expenditure cointegrate at 5 percent significance level. This implies there exist a long run relationship between the log of government expenditure and the log of government revenues in Ghana.

\section{Test Results for Long Run Relationship}

To get a different perspective of the sustainability of debt issues in Ghana, the study performed a simple regression of government expenditure and its revenue. The results are shown in Table 6.

By regressing the natural log of government revenues on the natural log of its expenditure, it was observed that, there exist a positive relationship between government expenditure and revenue as they are on the path of convergence. The adjustment parameter of the lag term of government expenditure implies that a deviation of the expenditure from its trend is quickly adjusted to its long run equilibrium which was statistically significant at 1 percent. The study observes that when government revenue increases by 1 percent, government expenditure increases by 0.73 percent and this is statistically significant at 1 percent. Further, the study then proceeded to impose a strict condition that the coefficient of government revenue must be equal to one i.e. to test the null hypothesis that $\alpha_{1}=1$.

The results from the Wald test estimation presented in the table shows that,

Table 6. ARDL long run relationship.

\begin{tabular}{|c|c|c|c|}
\hline \multicolumn{2}{|c|}{ ARDL regression based on AIC } & \multicolumn{2}{|c|}{ Dependent variable: LnExp } \\
\hline Regressor & Coefficient & Standard Error & T Statistic \\
\hline $\operatorname{LnExp}(-1)$ & -0.40 & $(0.121)$ & $-3.31^{\star * *}$ \\
\hline Lnrev & 0.725 & $(0.1861)$ & $3.89^{* * *}$ \\
\hline \multicolumn{4}{|c|}{ Wald Test Restriction } \\
\hline \multicolumn{2}{|c|}{ test $\left(\alpha_{1}=1\right)$} & \multicolumn{2}{|c|}{$F(1,20)=2.18$} \\
\hline \multicolumn{2}{|c|}{ (1) $\alpha_{1}=$} & \multicolumn{2}{|c|}{ Prob $>F=0.1552$} \\
\hline
\end{tabular}

$* * *, * * \& \&^{*}$ denotes $1 \%, 5 \%$ \& 10\% Significant levels respectively. Source: Authors' own computation. Data from the World Bank, and the Ministry of Finance Ghana. All results are obtained from Stata 14 econometric package. 
$\alpha_{1}$ is statistically close to unity so the study does not reject this null hypothesis because it was also statistically significant. This indicates that the solvency condition holds for Ghana.

\section{Conclusion}

The rising debt levels in Ghana have led to serious questions on the sustainability of the public debt. This in turn creates, an incoherent fiscal policy. The main objective of the study is to find out if public debt is sustainable and its effect on fiscal stability in Ghana. The study used annual time series data from 1990 to 2016 sourced from the World Bank database and Ministry of Finance Ghana. The study revealed that, one unit increase in government spending has severe consequence on the stability of fiscal policy; therefore government expenditure must be controlled. Public debt of Ghana is generally sustainable and policy makers react positively to rising debt levels. The study concluded that the fiscal solvency condition holds for Ghana. It is therefore recommended that government must avoid some cyclical spending such as domestic capital expenditure which usually rises during election cycle to ensure the shock of transitory spending on primary balance is reduced. Government must continue with its debt reprofiling policy such that most short term debt can be converted to long term debt which will reduce and spread the interest payments to its long term benefit. It is imperative for fiscal policies to be legislated so that successive governments would see to it its full implementation. This will help in fiscal sustainability in the long run. Fiscal authorities must always ensure public debt do not explode in the long run. It is crucial for the government to always avoid build up public debt. Unavailability of data restricted the study to a 27 year span, so future studies must consider exploring other data sources and also include other macroeconomic variables that have relationship with primary fiscal balance and public debt to the study.

\section{References}

[1] Sowa, N.K. (2002) Managing Ghana's Domestic Debt. CEPA Research Working Paper. Centre for Policy Analysis, Accra.

[2] Reinhart, C. and Rogoff, K. (2009) Banking Crises: An Equal Opportunity or Menace. NBER Working Papers, No. 14587.

[3] Harold, G.M. (1943) The New Philosophy of Public Debt. The Brookings Institution, 1943-Business and Economics, Vol. 45.

[4] Institute for Fiscal Studies (IFS) (2015) Ghana: Public Debt and Debt Sustainability Issues. Occasion Paper No. 3.

[5] Kusi, N.K. (2015) Ghana's Fiscal Challenge and the IMF Bailout. Institute of Fiscal Studies, Accra.

[6] International Monetary Fund (IMF) (2015) Ghana Request for a Three-year Arrangement under the Extended Credit Facility Staff Report; Press Release and Statement by the Executive Director for Ghana-IMF Country Report No. 15/103.

[7] Ministry of Finance (MoFEP) (2017) The Budget Statement and Economic Policy of 
the Government of Ghana for the 2017 Financial Year. March 2017.

http://www.mofep.gov.gh/

[8] Chouraqui, J.C., Jones, B.R. and Montador, R.B. (1986) Public Debt in a Medium-Term Context and Its Implications for Fiscal Policy. OECD Economics and Statistics Department Working Paper No. 30.

[9] Dornbusch, R. and Fischer, S. (2000) Macroeconomics. 6th Edition.

[10] Bowen, W.G., Davis, R.G. and Kopf, D.H. (1960) The Public Debt, a Burden on Future Generations. American Economics Review, 50, 701-706.

[11] Pigou, A.C. (1929) A Study in Public Finance. 2nd Edition, Macmillan, London.

[12] Barro, R. (1974) Are Government Bonds Net Wealth? Journal of Political Economy, 82, 1095-1117. https://doi.org/10.1086/260266

[13] Levine, R. (2005) Finance and Growth: Theory, Evidence and Mechanisms. In: Aghion, P. and Durlauf, S., Eds., Handbook of Economic Growth, Vol. 1, Part 1, North Holland, Amsterdam, 865-934.

[14] Holtfrerich, C., Feld, L.P., Heun, W., Illing, W., Kirchgassner, G., Kocka, J., Schularick, M., Streeck, W., Wagschal, U., Walter, S. and von Weizsacker, C.C. (2015) Government Debt: Causes, Effects and Limits. Union of the German.

[15] Blanchard, O.J. (1993) Consumption and Recession of 1990-1991. American Economic Review, 83, 270-274.

[16] Gali, J. (1994) Government Size and Macroeconomic Stability. European Economic Review, 38, 117-132. https://doi.org/10.1016/0014-2921(94)90009-4

[17] Fatas, A. and Mihov, I. (2001) Government Size and Automatic Stabilizers: An International Evidence. Journal of International Economics, 55, 3-28. https://doi.org/10.1016/S0022-1996(01)00093-9

[18] Ramey, G. and Ramey, V. (1995) Cross Country Evidence on the Link between Volatility and Growth. American Economic Review, 85, 1138-1151.

[19] Blanchard, O.J., Dell'Ariccia, G. and Mauro, P. (2010) Rethinking Macroeconomics. IMF Staff Position Note. SPN/10/03.

[20] Underwood (1990) Sustainability of International Debt. Mimeo.

[21] Cohen, D. (1995) Sustainability of African Debt. International Economic Association Series. https://doi.org/10.1596/1813-9450-1621

[22] D’Erasmo, P., Mendoza, G.E. and Zhang, J. (2015) What Is Sustainable Public Debt? https://doi.org/10.3386/w21574

[23] Blanchard, O.J., Chouraqui, J., Hagemann, R.P. and Sartor, N. (1990) The Sustainability of Fiscal Policy: New Answers to an Old Question. OECD Economic Studies, $15,7-36$.

[24] Pattilo, C., Poirson, H. and Ricci, L. (2002) External Debt and Growth. IMF Working Paper No. 02/69.

[25] Kohler-Toglhofer, W. and Zagler, M. (2007) The Composition of the Government Budget and the Dynamics of Public Debt. FinanzArchiv. Public Finance Analysis, 63, 244-263. https://doi.org/10.1628/001522107X220099

[26] Mendoza, G.E. and Ostry, D.J. (2008) International Evidence on Fiscal Policy: Is Fiscal Policy “Responsible”? Journal of Monetary Economics, 55, 1081-1093. https://doi.org/10.1016/j.jmoneco.2008.06.003

[27] Checherita-Westphal, C. and Rother, P. (2012) Debt and Growth New Evidence for the Euro Area. European Central Bank, Working Paper Series, No. 1450/July 2012.

[28] Turner, D. and Spinelli, F. (2011) Explaining the Interest Rate-Growth Differential 
Underlying Government Debt Dynamics. OECD Economics Department Working Papers. https://doi.org/10.1787/5kg0k706v2f3-en

[29] Blot, C., Cochard, M., Ducoudre, B., Schweisguth, D., Timbeau, X. and Creel, J. (2014) Fiscal Consolidation, Public Debt and Output Dynamics in the Euro Area: Lessons from a Simple Model with Time-Varying Fiscal Multipliers. OFCE \& ESCP Europe, Working Paper. https://hal-sciencespo.archives-ouvertes.fr/hal-01052440 https://doi.org/10.3917/redp.246.0953

[30] Asiama, J., Akosah, N. and Owusu-Afriyie, E. (2014) An Assessment of Fiscal Sustainability in Ghana. Bank of Ghana Working Paper: WP/BOG-2014/09.

[31] Frimpong, J.M. and Oteng-Abayie, E.F. (2006) The Impact of External Debt on Economic Growth in Ghana: A Cointegration Analysis. Journal of Science and Technology, 26, 122-131.

[32] Owusu-Nantwi, V. and Erickson, C. (2016) Public Debt and Economic Growth in Ghana. African Development Review, 28, 116-126. https://doi.org/10.1111/1467-8268.12174

[33] Bohn, H. (1998) The Behabiour of US Public Debt Deficits. The Quarterly Journal of Economics, 113, 949-963. https://doi.org/10.1162/003355398555793

[34] Bohn, H. (2008) The Sustainability of Fiscal Policy in the United States. In: Neck, R. and Sturm, J.-E., Eds., Sustainability of Public Debt, MIT Press, Cambridge. https://doi.org/10.7551/mitpress/9780262140980.003.0002

[35] Kustepeli, Y. and Onel, G. (2004) Fiscal Deficit Sustainability with a Structural Break: An Application to Turkey. İzmir-Turkey, Dokuz Eylül University.

[36] Hamilton, J.D. and Flavin, A.M. (1986) On the Limitations of Government Borrowing: A Framework for Empirical Testing. American Economic Review, 76, 808-819. http://ideas.repec.org/a/aea/aecrev/v76y1986i4p808-19.html

[37] Abiad, A. and Ostry, J.D. (2005) Primary Surpluses and Sustainable Debt Levels in Emerging Market Countries. IMF Policy Discussion Paper, PDP/05/6, 1-19.

[38] Afonso, A. (2005) Fiscal Sustainability: The Unpleasant European Case of Countercyclical a Fiscal Policy. 61.

[39] Buiter, W.H., Persson, T. and Minford, P. (1985) A Guide to Public Sector Debt and Deficits. Economic Policy, 1, 13-79. http://www.jstor.org/stable/1344612 https://doi.org/10.2307/1344612

[40] Chalk, N. and Hemming, R. (2000) Assessing Fiscal Sustainability in Theory and Practice. International Monetary Fund, WP/00/81.

[41] Turrini, A. (2008) Fiscal Policy and the Cycle in the Euro Area: The Role of Government Revenue and Expenditure. European Economy, Economic Papers/323.

[42] Neck, R. and Sturm, J. (2008) Sustainability of Public Debt. MIT Press. Cambridge. https://doi.org/10.7551/mitpress/9780262140980.001.0001

[43] Escalano, J. (2010) A Practical Guide to Public Debt Dynamics, Fiscal Sustainability and Cyclical Adjustment of Budgetary Aggregates: Technical Notes and Manuals. International Monetary Fund, 1-25. https://doi.org/10.5089/9781462396955.005

[44] Égert, B. (2010) Fiscal Policy Reaction to the Cycle in the OECD: Pro- or Counter-Cyclical? OECD Economics Department Working Papers, No. 763, OECD Publishing.

[45] Holmes, J.M., Jesús, O. and Panagiotidis, T. (2007) Are EU Budget Deficits Sustainable? Waikato University, Hillcrest.

[46] Quintos, C.E. (1995) Sustainability of the Deficit Process with Structural Shifts. 
Journal of Business and Economic Statistics, 13, 409-417.

[47] Bohn, H. (2005) The Sustainability of Fiscal Policy in the United Stated. Working Paper Series 1446, CESifo Group Munich.

[48] Pesaran, M.H., Shin, Y. and Smith, R.J. (2001) Bounds Testing Approaches to the Analysis of Level Relationships. Journal of Applied Econometrics, 16, 289-326. https://doi.org/10.1002/jae.616

[49] Alesina, A. and Tabellini, G. (2005) Why Is Fiscal Policy often Procyclical? NBER Working Series. Working Paper/11600.

[50] Erbil, N. (2011) Is Fiscal Policy Procyclical in Developing Oil-Producing Countries? IMF Working Paper WP/11/171.

[51] Institute of Economic Affairs (IEA) (2015) A Review of the Ghanaian Economy in 2013-2014. Theme: Ghana's Public Financial Management. IEA, Accra. 